\title{
Piping by queens of Apis cerana Fabricius 1793 and Apis koschevnikovi v Buttel-Reepen 1906
}

\author{
GW Otis ${ }^{1}, \mathrm{~K}$ Patton ${ }^{1}$, S Tingek ${ }^{2}$ \\ 1 Department of Environmental Biology, University of Guelph, Guelph, ON, N1G2W1, Canada \\ ${ }^{2}$ Honey Bee Research Section, Agricultural Research Station, Peti Surat 197, \\ 89909 Tenom, Sabah, Malaysia
}

(Received 1 February 1993; accepted 1 August 1994)

\begin{abstract}
Summary - Piping queens of Apis cerana and A koschevnikovi were recorded in Sabah, Malaysia. The tooting calls of the 2 species were similar and consisted of a single continuous call lasting 2-5 s. In contrast, $A$ mellifera queens give a 1-2 s tone followed by several shorter tones. Quacking by an $A$ koschevnikovi queen in a queen cell was very similar to the quacking reported for $A$ mellifera except the tempo was more rapid (4.39 quacks/s vs 3.0 quacks/s).
\end{abstract}

queen piping / Apis cerana / Apis koschevnikovi

\section{INTRODUCTION}

Queen piping behaviour has been reported and studied for only 1 species of honey bee, Apis mellifera $\mathrm{L}$. When piping, the queen of $A$ mellifera crouches on the comb and vibrates her wing muscles, thereby producing vibrations that travel through the comb and are detected by other bees with their legs (Simpson, 1964; Michelsen et al, 1986). The piping is also heard as a clearly audible signal, which consists of a long tone followed by a series of short tones of less than $0.5 \mathrm{~s}$ (Wenner, 1962). This type of signal is often referred to as 'tooting'. Queens confined by workers in their cells often respond with a rapid series of short chirps referred to as 'quacking' (Wenner, 1962).
These two types of piping signals are important in regulating the emergence of virgin queens and the departure of afterswarms in A mellifera (Butler, 1609; Huber, 1814; Simpson and Cherry, 1969; Grooters, 1987).

During a bee collecting trip to Sabah, colonies of A koschevnikovi and A cerana were observed. We were fortunate to have the opportunity to record tooting and quacking signals of piping queens, which we describe here for the first time.

\section{MATERIALS AND METHODS}

We inspected managed colonies of $A$ cerana and A koschevnikovi at the Tenom Agricultural Research Station in Tenom, Sabah, East 
Malaysia $\left(5^{\circ} 10^{\prime} \mathrm{N}, 115^{\circ} 57^{\prime} \mathrm{E}\right)$. When we encountered colonies in which the queen was piping, we recorded the audible sound with a Sony Professional Walkman tape recorder equipped with a Sony F99LT microphone and Sony UX-Pro90 Type II $\left(\mathrm{CrO}_{2}\right)$ high bias tape. Recordings were made from opened hives to place the microphone near the piping bees. We recorded tooting sequences from 2 colonies of $A$ koschevnikovi on May 4 , and from 1 colony of $A$ cerana on May 5,1988 . In addition, the quacking pattern of a queen confined in a queen cell was recorded from one of the A koschevnikovi colonies.

The duration of each piping call and the time intervals between calls were timed twice from the recordings using a hand-operated stop watch. If there was any discrepancy between the 2 measurements, the measurement in question was taken again to resolve the discrepancy. The tape was slowed down slightly to count the number of abdominal thumps.

Sonographs were obtained by digitizing the audible taped signal with a Macintosh IIx conputer equipped with GW Instruments Speech Lab hardware and software. We recognize that this method has several limitations (Michelsen et al, 1986), but it is adequate to study the general pattern of the piping rather than details of sound frequencies and intensities.

\section{RESULTS}

The tooting calls of 2 A koschernikovi queens differed somewhat (table I) but always consisted of a single tone 1.1-5.6 s long. The frequency of the tooting signal usually rose rapidly at the start of the sig- nal, after which it remained fairly constant at a fundamental frequency of about $2700 \mathrm{~Hz}$ before decreasing slightly at the end of the call (fig 1a and b). However, some calls began at the main frequency (fig 1c) while others failed to decrease in frequency at the end (fig 1d). Some calls exhibited considerable frequency modulation either at the beginning (fig 1d) or the end (fig 1c) of the call. The frequency range of the fundamental signal varied from 2290 to $2890 \mathrm{~Hz}$. In our recordings there were 7 harmonics with maximum frequency of about $9000 \mathrm{~Hz}$. The intensity of audible sound was generally strongest in the middle of the toot.

Figure 1e depicts a typical $A$ cerana toot. The $A$ cerana queen tooted in a manner very similar to that of $A$ koschevnikovi queen 1 (table I), except the interval between toots was longer for unknown reasons.

One queen of each species beat its abdomen on the comb at the end of its tooting signal. This behaviour has not been reported previously and needs to be documented more fully.

Quacking was heard only in one $A$ koschevnikovi colony. Long series of quacks from a queen confined in a queen cell alternated with toots from a virgin queen moving freely in the colony. The frequency of the calls was very broad, $330-3100 \mathrm{~Hz}$, and the tones, which lasted an average of $0.06 \mathrm{~s}$, were regularly spaced every $0.228 \mathrm{~s}(n=$ 31; fig 1f).

Table I. Descriptive statistics for piping (tooting) signals of 1 A cerana queen and $2 A$ koschevnikovi queens.

Species

Duration of piping (s) $x \pm S D(n)$

$4.3 \pm 1.2(9)$

A cerana

A koschevnikovi (1)

A koschevnikovi (2)
$4.3 \pm 0.6(45)$

$2.4 \pm 0.8(10)$
Interval between piping (s)

$\mathrm{x} \pm S D(\mathrm{n})$

$$
\begin{gathered}
77.6 \pm 77.1(8) \\
14.0 \pm 9.1(40) \\
7.1 \pm 8.6(8)
\end{gathered}
$$




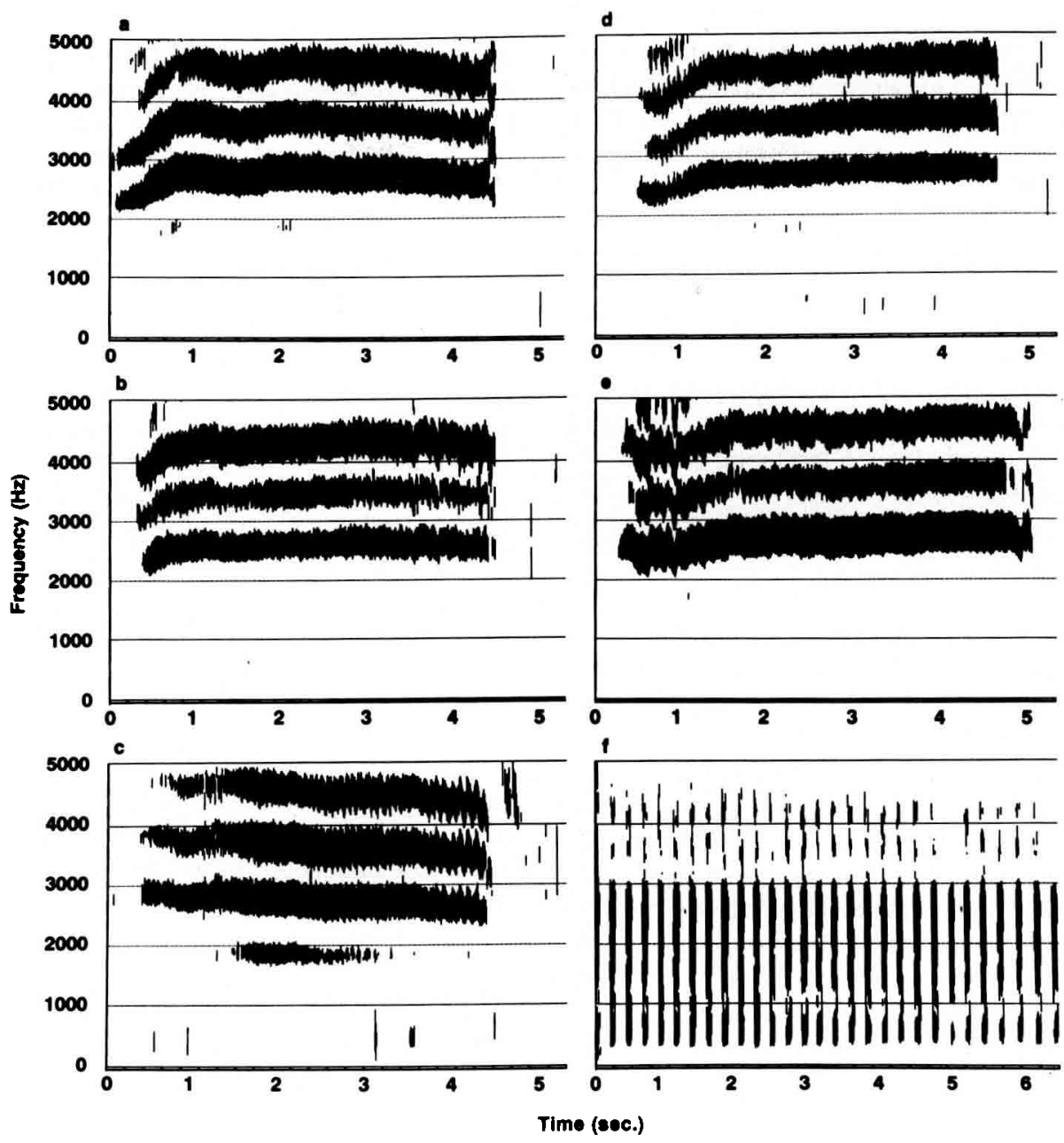

Fig 1. Sonographs of piping calls of Asian honey bees: 1a-d: tooting calls of $A$ koschevnikovi; 1 e: tooting call of $A$ cerana; and 1f: quacking call of $A$ koschevnikovi. Note the time scale for $1 \mathrm{f}$ is different from the other 5 figures.

\section{DISCUSSION}

The piping (tooting) signals of $A$ cerana and A koschevnikovi are similar. From the limited data available, they have the same general pattern of a single continuous tone. In contrast, the tooting signals reported for $A$ mellifera consist of 1 longer call of $1-2 \mathrm{~s}$ followed by several shorter calls of $0.14-1.50 \mathrm{~s}$ given at approximately $0.5 \mathrm{~s}$ intervals (Wenner, 1962; Michelsen et al, 1986).

The quacking calls of $A$ koschevnikovi and $A$ mellifera are similar in character but possibly different in tempo. We recorded an average of 4.39 quacks/s for $A$ koschevnikovi while $A$ mellifera is reported to make about 3 calls/s ( 2.56 calls/s, calculated from Michelsen et al, 1986; 3.2 calls/s, calculated from Wenner, 1962). 
Other than reporting them, we have not attempted to interpret the piping frequencies in this study for several reasons. First, the harmonics we recorded in our sonographs may not be meaningful (Michelsen et al, 1986). Secondly, we did not know the age of the queens we recorded, and the piping frequency may be affected by queen age (Michelsen et al, 1986). Finally, our recorded frequencies are quite different from those reported for $A$ mellifera $(350-480 \mathrm{~Hz}$, Michelsen et al, 1986; $420 \mathrm{~Hz}$, Wenner, 1962), even though the taped calls of all 3 species sounded similar.

In both $A$ cerana and $A$ koschevnikovi, piping occurred in colonies that had swarmed but did not yet have new laying queens. From the condition of the queen cells, we determined that only the first 1 or 2 queens had emerged and no afterswarms had yet departed. This agrees with the pattern of piping in A mellifera (Butler, 1609; Simpson and Cherry, 1969). An $A$ andreniformis colony near Johor, Malaysia, also had a piping queen at a similar point in the swarming sequence (personal observation). It seems likely that piping regulates aspects of colony behaviour during the afterswarming process in all of these honey-bee species.

\section{ACKNOWLEDGMENTS}

T Eong Beok and M Tulas of the Department of Agriculture, Sabah, facilitated study at the Tenom Research Station. A Kalito and KP Mathew assisted in the field. W Cade (Brock University) provided access to his Macintosh Ilx computer, and his students $M$ Ciceran and $K$ Souroukis generated the sonographs of the piping signals. This research was supported by a University of Guelph Research Leave Grant to GW Otis, a grant from the International Development Research Centre of Canada to the Universiti Pertanian Malaysia, and the Department of Agriculture, East Malaysia.

Résumé - Le chant des reines d'Apis cerana Fabricius 1793 et d'Apis koschev- nikovi v Buttel-Reepen 1906. Nous avons analysé le chant des reines d' $A$ koschevnikovi et d'A cerana et les avons comparés avec ceux d'A mellifera $L$. Des colonies possédant des reines vierges qui chantaient ont été observées à la station de recherches agricoles de Tenom, Sabah, Malaisie. Le chant des reines écloses ou "tooting" (1 reine cerana et 2 reines koschevnikovi) et celui des reines enfermées dans leur cellule ou "quacking" (1 reine koschevnikovi) a été enregistré sur bande magnétique. Des sonogrammes ont été établis pour les enregistrements les plus représentatifs (fig 1). Le chant des reines qui viennent d'éclore est semblable chez les 2 espèces et consiste en un signal unique et continu de 1,1 à 5,6 s (tableau I). II diffère nettement des signaux décrits pour $A$ mellifera qui émet un seul son long et plusieurs sons courts. Le chant de la reine de koschevnikovi avant l'éclosion ressemble, en plus rapide, à celui de mellifera (4,39 vs 3,0 son/s). Nous pensons que le chant des reines contribue, dans toutes les espèces, à réguler le comportement de la colonie en période de post-essaimage.

Apis cerana / Apis koschevnikovi/ reine / chant

Zusammenfassung - Tüten und Quaken der Königinnen von Apis cerana Fabricius 1793 une Apis koschevnikovi v Buttel-Reepen, 1906. Wir berichten über die Königinnensignale Tüten und Quaken bei $A$ koschevnikovi und $A$ cerana und vergleichen sie mit den publizierten Werten von Apis mellifera L. Völker mit tütenden Königinnen wurden in der Landwirtschaftlichen Forschungsstation in Tenom, Sabah, Malaysia beobachtet. Vom Tüten wurden bei $1 A$ cerana und bei 2 A koschevnikovi Königinnen und vom Quaken bei 1 A koschevnikovi Königin Tonbandaufnahmen gemacht. Die Dauer aller Töne wurden mit einer Stopuhr bestimmt. Von den entsprechenden Auf- 
nahmen wurden Sonogramme angefertigt (Abb 1). Königinnen beider Arten erzeugten ähnliche Tütsignale, die aus einem einzigen langanhaltenden Ton von 1,1-5,6 s bestand (Tabelle I). Damit unterscheiden sie sich deutlich von den beschriebenen Signalen von A mellifera, deren Königinnen einen langen und mehrere kurze Tütsignale erzeugen und auch nicht mit dem Abdomen auf die Wabe pochen. Die Quaksignale von $A$ koschevnikovi sind ähnlich, aber schneller als für $A$ mellifera beschrieben wurde (4,39 vs 3,0 Quaksignale/s). Wir vermuten, daß Quaken und Tüten bei den meisten Arten der Honigbiene vorkommen und in der Zeit der Nachschwärme einen regulierenden Einfluß auf das Verhalten des Volkes hat.

Königin / Tüten und Quaken / Apis koschevnikovi / Apis cerana

\section{REFERENCES}

Butler C (1609) The Feminine Monarchie. Barnes, Oxford, UK

Grooters HJ (1987) Influences of queen piping and worker behaviour on the timing of emergence of honey bee queens. Insectes Soc 34, 181-193

Huber F (1814) New Observations Upon Bees. American Bee Journal, Hamilton, IL, USA (Translated by CP Dadant, 1926)

Michelsen A, Kirchner WH, Andersen BB, Lindauer M (1986) The tooting and quacking vibration signals of honeybee queens: a quantitative analysis. $J$ Comp Physiol A 158, 605-611

Simpson J (1964) The mechanism of honey-bee queen piping. $Z$ Verg/ Physio/ 48, 277-282

Simpson J, Cherry SH (1969) Queen confinement, queen piping and swarming in Apis mellifera colonies. Anim Behav 17, 271-278

Wenner AM (1962) Communication with queen honey bees by substrate sound. Science 138, 446448 